\title{
Enteropathy complicating maintenance therapy in acute lymphoblastic leukaemia
}

\author{
I J LEWIS, D MAINWARING, AND J MARTIN
}

Regional Unit of Paediatric Haematology and Oncology, Department of Child Health, Alder Hey Children's Hospital, Liverpool

SUMMARY Seven patients being treated for acute lymphoblastic leukaemia between March 1976 and March 1981, in accordance with Medical Research Council protocols, developed clinical malabsorption while on maintenance chemotherapy. All of them received weekly methotrexate and 6 of the 7 were given co-trimoxazole. Five patients had folate deficiency. Stopping the antileukaemic therapy led to a resolution of gastrointestinal symptoms. A combined effect of methotrexate and co-trimoxazole is postulated.

Many of the drugs used in treating acute lymphoblastic leukaemia (ALL) cause gastrointestinal symptoms, particularly nausea and vomiting. Methotrexate commonly causes mucositis and occasionally diarrhoea; it has been shown to alter jejunal morphology ${ }^{1}$ and, more recently, has been implicated in causing impaired xylose absorption in children with leukaema. ${ }^{2}$ Sporadic reports have appeared implicating methotrexate in causing a clinical malabsorption syndrome. ${ }^{3}$

Seven children with ALL exhibited clinical and biochemical criteria of malabsorption while on maintenance therapy, which included regular weekly methotrexate.

\section{Patients}

In the 5 years to March 1981, 81 children were diagnosed as having ALL at this hospital. The majority of patients were treated according to Medical Research Council UK ALL trials. Fortyfive were treated with maintenance regimens using intermittent methotrexate, 6-mercaptopurine (6-MP) cytosine arabinoside, vincristine, and prednisolone. (UK ALL IV, UK ALL V 'intermittent', and UK ALL VI). Thirty-six were treated with regimens using weekly methotrexate, 6-MP, vincristine, and prednisolone (UK ALL V 'continuous', UK ALL V 'gaps', and UK ALL VIII) (Table 1).

During this time 7 of the patients on maintenance therapy, including weekly methotrexate, presented with gastrointestinal symptoms that suggested a severe enteropathy. Six of these patients were entered into UK ALL trials. The first patient was initially entered into UK ALL IV but after 18 months was changed to UK ALL V (gaps) maintenance treatment. Two patients were entered into UK ALL V ( 1 continuous, 1 gaps) and 3 patients into UK ALL VIII. The other patient was too young at diagnosis for entry into the trials but followed the UK ALL V (gaps) schedule except that cranial irradiation was omitted and regular intrathecal methotrexate substituted.

Table 1 Maintenance drug regimens of children treated for acute lymphoblastic leukaemia 1976-81

\begin{tabular}{|c|c|c|}
\hline & \multicolumn{2}{|l|}{ Methotrexate } \\
\hline & Weekly & Intermittently \\
\hline Methotrexate dosage & $20 \mathrm{mg} / \mathrm{m}^{2}$ per dose & $\begin{array}{l}10-15 \mathrm{mg} / \mathrm{m}^{2} \text { per dose } \\
3-5 \text { day course given } \\
3-4 \text { weekly }\end{array}$ \\
\hline Other maintenance drugs & $\begin{array}{l}\text { 6-mercaptopurine, vincristine, } \\
\text { prednisolone }\end{array}$ & $\begin{array}{l}\text { 6-mercaptopurine, cytosine arabinoside, } \\
\text { vincristine, prednisolone }\end{array}$ \\
\hline No of children & 36 & 45 \\
\hline No receiving co-trimoxazole & 27 & 31 \\
\hline No developing cateropathy & $\begin{array}{l}7 \\
\text { (6 receiving co-trimoxazole) }\end{array}$ & 0 \\
\hline
\end{tabular}


Six of the patients with malabsorption received co-trimoxazole $(4-8 \mathrm{mg} / \mathrm{kg}$ a day) as prophylaxis against Pneumocystis carinii.

\section{Methods}

Small-bowel biopsies were performed using a Crosby capsule. Mucosal disaccharidase activities were estimated by a semi-quantitative assessment after incubation with sugar. Standard 1-hour blood D-xylose absorption tests were performed in patients weighing less than $30 \mathrm{~kg}$. ${ }^{4}$ Serum and red cell folate measurements were by radioassay kit (Quantamate $^{\text {TM11 }}$ B-12/folate, Bio-Rad Laboratories).

\section{Clinical details (Table 2)}

The onset of gastrointestinal symptoms varied between 6 weeks and 33 months from diagnosis. The 3 children treated with the more intensive UK ALL VIII induction regimen (Cases 5, 6, and 7) presented before completing their first 12-week maintenance cycle. Although the symptoms of 2 of them (Cases 6 and 7) started before normal maintenance treatment, these were initially mild and remitting and were thought to be due to the more toxic nature of induction. Their symptoms gradually worsened and investigations were performed 15 (Case 6) and 11 (Case 7) weeks after initial diagnosis.

All the patients presented with similar symptoms of anorexia, intermittent vomiting, bowel disturbance including steatorrhoea and abdominal distension. All exhibited pronounced weight loss and none had oral ulceration. The 4 patients whose clinical symptoms developed later had been on maintenance treatment for longer than 6 months. They exhibited a period of poor weight gain for between 4 and 16 months before the onset of gastrointestinal symptoms.

\section{Results}

The patients were investigated for evidence of bacterial, viral, or protozoal infection. Case 1 was found to have Escherichia coli $\mathrm{O} 86$ in his stools on one occasion. This particular organism is reported as causing infantile gastroenteritis but does not generally cause symptoms in older children. None

Table 2 Clinical details and investigative findings of children with acute lymphoblastic leukaemia having symptoms of malabsorption

\begin{tabular}{|c|c|c|c|c|c|c|c|c|c|c|c|}
\hline Case & $\begin{array}{l}\text { Age at } \\
\text { diagnosis } \\
\text { (years) }\end{array}$ & $\operatorname{Sex}$ & $\begin{array}{l}\text { Time between } \\
\text { diagnosis } \\
\text { and onset of } \\
\text { symptoms } \\
\text { (months) }\end{array}$ & $\begin{array}{l}\text { Clinical } \\
\text { presentation }\end{array}$ & $\begin{array}{l}\text { Weight } \\
\text { loss }(\mathrm{kg}) \\
(\% \text { of } \\
\text { body } \\
\text { weight })\end{array}$ & $\begin{array}{l}\text { l-hour } \\
\text { blood } \\
\text { D-xylose } \\
(\text { mmol } / l)\end{array}$ & $\begin{array}{l}\text { Serum } \\
\text { folate } \\
(\mathrm{mg} / \mathrm{l}) \\
(\text { normal } \\
3 \cdot 5-12)\end{array}$ & $\begin{array}{l}\text { Red cell } \\
\text { folate } \\
(\text { mg/l) } \\
(\text { normal } \\
200-700)\end{array}$ & $\begin{array}{l}\text { Decrease } \\
\text { in } \mathrm{Hb} \\
\text { level } \\
(\mathrm{g} / \mathrm{dl})\end{array}$ & $\begin{array}{l}\text { Marrow } \\
\text { morphology }\end{array}$ & $\begin{array}{l}\text { Small-bowel } \\
\text { biopsy }\end{array}$ \\
\hline 1 & $2 \cdot 9$ & $\mathbf{M}$ & 33 & $\begin{array}{l}\text { Lethargy, anorexia, } \\
\text { loose offensive } \\
\text { stools }\end{array}$ & $\begin{array}{l}3.4 \\
(22 \%)\end{array}$ & $\downarrow 0.7$ & NT & N'T & $\downarrow 2$ & $\begin{array}{l}\text { Megalo- } \\
\text { blastic } \\
\text { changes } \\
\downarrow \text { Myelo- } \\
\text { poiesis }\end{array}$ & Normal \\
\hline 2 & $5 \cdot 5$ & $\mathbf{F}$ & 30 & $\begin{array}{l}\text { Anorexia, intermittent } \\
\text { vomiting, abdominal } \\
\text { distension, pale } \\
\text { loose stools }\end{array}$ & $\begin{array}{l}2 \cdot 1 \\
(10 \%)\end{array}$ & $\downarrow 0.9$ & $\begin{array}{l}4 \cdot 7 \\
\quad \text { normal }\end{array}$ & 235 & $\begin{array}{l}\text { None } \\
\text { al }\end{array}$ & Normal & $\begin{array}{l}\text { Abnormal } \\
\downarrow \text { Villous: } \\
\text { crypt ratio } \\
1 \cdot 3: 1 \\
\uparrow \text { Cellularity }\end{array}$ \\
\hline 3 & $3 \cdot 0$ & $\mathbf{M}$ & 8 & $\begin{array}{l}\text { Anorexia, intermittent } \\
\text { vomiting, abdominal } \\
\text { distension, loose } \\
\text { offensive stools }\end{array}$ & $\begin{array}{l}1 \cdot 8 \\
(12 \%)\end{array}$ & $\downarrow 0.7$ & $\downarrow 1 \cdot 0$ & $\downarrow 60$ & $\downarrow 3$ & $\begin{array}{l}\text { Megalo- } \\
\text { blastic } \\
\text { changes }\end{array}$ & $\begin{array}{l}\text { Abnormal } \\
\downarrow \text { Villous: } \\
\text { crypt ratio } \\
1 \cdot 2: 1 \\
\downarrow \text { Cellularity }\end{array}$ \\
\hline 4 & 0.9 & $\mathbf{M}$ & 18 & $\begin{array}{l}\text { Anorexia, abdominal } \\
\text { distension, inter- } \\
\text { mittent diarrhoea }\end{array}$ & $\begin{array}{l}1 \cdot 3 \\
(10 \%)\end{array}$ & $\downarrow 0 \cdot 2$ & $\downarrow 2 \cdot 6$ & NT & $\mathbf{N}$ & Normal & $\begin{array}{l}\text { Abnormal } \\
\downarrow \text { Villous: } \\
\text { crypt ratio } \\
1: 1\end{array}$ \\
\hline 5 & $14 \cdot 5$ & $\mathbf{F}$ & 4 & $\begin{array}{l}\text { Anorexia, lethargy, } \\
\text { pale offensive stools }\end{array}$ & $\begin{array}{l}8 \cdot 0 \\
(18 \%)\end{array}$ & NT & $\downarrow 1 \cdot 1$ & $\downarrow 64$ & $\downarrow 4$ & $\begin{array}{l}\text { Megalo- } \\
\text { blastic } \\
\text { changes }\end{array}$ & NT \\
\hline 6 & $7 \cdot 5$ & $\mathbf{M}$ & $2 \frac{1}{2}$ & $\begin{array}{l}\text { Anorexia, intermittent } \\
\text { vomiting, frequent } \\
\text { pale offensive stools, } \\
\text { angular stomatitis, } \\
\text { smooth tongue }\end{array}$ & $\begin{array}{l}8.9 \\
(30 \%)\end{array}$ & NT & $\downarrow 1 \cdot 0$ & NT & $\downarrow 4$ & $\begin{array}{l}\text { Megalo- } \\
\quad \text { blastic } \\
\text { changes } \\
\downarrow \text { Red blood } \\
\text { count } \\
\text { precursors }\end{array}$ & $\begin{array}{l}\text { Abnormal } \\
\downarrow \text { Villous: } \\
\text { crypt ratio } \\
1 \cdot 3: 1 \\
\uparrow \text { Cellularity }\end{array}$ \\
\hline 7 & $7 \cdot 0$ & $\mathbf{M}$ & $1 \frac{1}{2}$ & $\begin{array}{l}\text { Anorexia, abdominal } \\
\text { distension, loose } \\
\text { stools }\end{array}$ & $\begin{array}{l}3 \cdot 7 \\
(21 \%)\end{array}$ & $\downarrow 0.5$ & $\downarrow 1 \cdot 0$ & $\downarrow 62$ & $\downarrow 4$ & $\begin{array}{l}\text { Megalo- } \\
\text { blastic } \\
\text { changes }\end{array}$ & Normal \\
\hline
\end{tabular}

$\downarrow$ Abnormally low value, $\mathrm{NT}=$ not tested. 
of the other patients had evidence of concurrent infection.

Haematological findings. Five patients each had a significant fall in haemoglobin concentration after the onset of symptoms, 2 needing blood transfusions. All 5 had megaloblastic changes present in bone marrow. Only one had any evidence of white cell depression and none had peripheral white cell or platelet counts that would have normally necessitated a reduction in drug dosage.

Folate studies. Serum folate was low in 5 of the 6 children tested and red cell folate was low in 3 of them. The one patient whose levels were within the normal range was not receiving co-trimoxazole.

One hour D-xylose test. Five patients were tested and all had abnormal values indicating malabsorption. Cases 5 and 6 were not tested as each weighed more than $30 \mathrm{~kg}$ at diagnosis and there is no evidence that this investigation is accurate in children over that weight. ${ }^{4}$

Small-bowel biopsy. Six children had successful biopsies and 2 of these were normal. The 4 abnormal biopsies showed a varying degree of sub-total villous atrophy (Figure). Increased cellular infiltrate was present in 2 biopsies and one showed decreased cellularity.

Two of the patients had decreased lactase activity but no other evidence of disaccharidase deficiency was present.

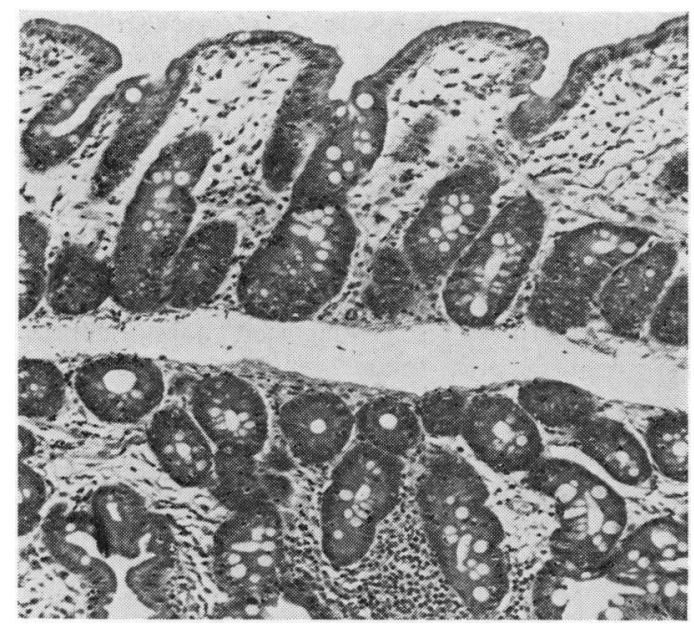

Figure Jejunal biopsy specimen from Case 4 before maintenance therapy was stopped, showing sub-total villous atrophy. $H \&$ E stain. $\times 30$.

\section{Patient follow-up}

Cases 1 and 2 had neared completion of their maintenance treatment when they presented with gastrointestinal symptoms and their therapy was stopped. The condition of both patients improved quickly and each exhibited rapid catch-up growth and weight gain. Case 2 had a repeat small-bowel biopsy 6 months later which showed complete resolution of previous changes.

Cases 3 and 4 stopped receiving methotrexate but continued with their other chemotherapy. Clinical symptoms resolved within 3 weeks in one and within 4 weeks in the other. Case 3 continued on the same regimen but has recently had methotrexate introduced in a modified dosage. He also receives folic acid supplements.

Case 5 stopped treatment for 4 weeks and her gastrointestinal symptoms gradually resolved. She was then restarted on 6-mercaptopurine, low-dose methotrexate, and co-trimoxazole with folic acid supplements.

Case 6 required a prolonged period of nasogastric tube feeding with an elemental diet, folate, and vitamin supplements. His symptoms stopped and a normal diet was reintroduced. Chemotherapy was restarted after a 6-week gap. He was reinduced with vincristine and prednisolone followed by normal maintenance therapy of 6-mercaptopurine and methotrexate. Co-trimoxazole has been continued with folate supplements.

In Case 7 methotrexate was stopped for a period of 2 weeks with gradual improvement of his symptoms. He was restarted on methotrexate in reduced dosage with folic acid supplements, and subsequently has gained weight.

All 7 patients have remained symptom free in complete remission.

\section{Discussion}

Gastrointestinal symptoms are common in patients receiving cytotoxic drugs but generally occur acutely after drug administration and are often regarded as unavoidable consequences of these agents. The patients described in this report experienced a more insidious, but severe enteropathy.

It is not surprising that the rapidly dividing cells of the small intestinal epithelium are at risk of damage when exposed to chemotherapeutic agents. The effects of the folate antagonists aminopterin and methotrexate on gastrointestinal epithelium have been studied extensively. Trier ${ }^{1}$ showed pronounced abnormalities in mucosalultrastructure when studying changes induced in human small-intestine after a single intravenous dose of methotrexate, 
light microscopical examination demonstrated little change apart from a decrease in cellular mitotic rate. Craft et al. ${ }^{2}$ demonstrated functional xylose malabsorption in children with ALL treated with weekly methotrexate. In that study the degree of malabsorption was shown to increase in relation to the cumulative dose of methotrexate. However, none of the children had clinical symptoms of malabsorption apart from slow growth.

Clinical malabsorption appears to be rare with most cancer chemotherapy. One of the very few reports $^{3}$ of a clinical enteropathy attributed to methotrexate suggested that gut toxicity might be related to an abnormally efficient enterohepatic circulation of methotrexate producing epithelial damage as a result of high intraluminal levels of the drug. Other work has failed to support the proposal that methotrexate-induced damage affects its own absorption. ${ }^{5}$

While accepting that methotrexate causes subclinical malabsorption and that clinical malabsorption may rarely occur in children treated for leukaemia, we did not observe any case before the first patient in this series, despite a long clinical experience of this agent. The subsequent identification of 6 other children with similar presentations in a short period has necessitated a search for additional or an alternative explanation.

All the patients described here received weekly oral methotrexate. Animal studies ${ }^{6}$ support the contention that a period of a week between methotrexate doses is not sufficient to allow recovery of intestinal function, particularly in the presence of folate depletion when there is an enhanced susceptibility to toxic mucosal damage.

Five of our patients had definite folate deficiency and a sixth had megaloblastic marrow changes. Furthermore, 4 patients exhibited sub-total villous atrophy. The question arises whether the folate deficiency resulted from toxic, mucosal damage similar to that seen in coeliac disease, or whether the folate deficiency induced mucosal damage. ${ }^{7}$

Long-term co-trimoxazole was introduced into our routine clinical practice after Hughes et al. ${ }^{8}$ had shown its effectiveness as a chemoprophylactic agent against $\boldsymbol{P}$. carinii infection in immunosuppressed patients. Both components of cotrimoxazole act as microbial folate inhibitors. Sulphonamides alone do not cause megaloblastic anaemia in man because mammals do not synthesise folate, instead requiring it as a vitamin. Trimethoprim is said to be highly inhibitory to bacterial dihydrofolate reductase, but a concentration 50000 times greater is needed to produce a similar inhibition of human enzyme. ${ }^{9}$ Reports of patients given long-term co-trimoxazole as prophylaxis against chronic pulmonary or renal tract infection have failed to find any significant changes in haematological or folate status. ${ }^{10} 11$ However, in patients who were already folate deficient the addition of cotrimoxazole has been reported as causing both an exacerbation of megaloblastic anaemia with failure to respond to haematinics ${ }^{12}$ and acute pancytopenia with megaloblastic arrest. ${ }^{13}$ It is therefore suggested that the addition of co-trimoxazole to a regimen containing another antifolate drug, methotrexate, may synergistically inhibit folate metabolism in rapidly dividing cells and precipitate symptoms in some patients.

A previous study ${ }^{8}$ failed to find any significant increase in clinical side effects in patients receiving prophylactic co-trimoxazole together with cancer chemotherapy. However, two problems exist in the interpretation of this finding. Firstly, the number of patients receiving both methotrexate and cotrimoxazole was not defined and, secondly, the interval between methotrexate doses was not given. In our experience both these factors appear to be relevant.

Dietary folate deficiency has probably played a role in precipitating the enteropathy described in this report. The 3 children who presented early in remission had all been anorexic during the more toxic UK ALL VIII regimen. It seems possible that dietary folate deficiency may have been precipitated by anorexia and consequently have exacerbated the proposed combined effect of methotrexate and cotrimoxazole on the intestinal mucosa.

Four of the patients reported here have continued on maintenance chemotherapy, including methotrexate. In addition they receive both co-trimoxazole and folic acid supplements. Co-trimoxazole has been given because the risk of $\boldsymbol{P}$. carinii pneumonitis is felt to be greater than the potential risks of enteropathy. Folic acid supplements have been given in an endeavour to prevent the adverse effects of the combination of these drugs. Subsequently the 4 patients have not exhibited any gastrointestinal symptoms and each appears to be growing well.

Growth deficiency has been observed in children treated for ALL. ${ }^{14}{ }^{15}$ It is suggested that subclinical malabsorption and folate deficiency precipitated by weekly oral methotrexate may be partly responsible. Furthermore, the addition of other folate antagonists-such as co-trimoxozole and possibly dietary folate deficiency induced by a more toxic induction regimen-may precipitate the enteropathy observed in our patients.

I $\mathbf{J} \mathbf{L}$ and $\mathbf{D} \mathbf{M}$ were supported by grants from the Alder Hey Children's Hospital Leukaemia Research Fund. 


\section{References}

1 Trier J S. Morphologic alterations induced by methotrexate in the mucosa of human proximal intestine. I. Serial observations by light microscopy. Gastroenterology 1962; 42: 295-305.

2 Craft A W, Kay H E M, Lawson D N, McElwain T J. Methotrexate induced malabsorption in children with acute lymphoblastic leukaemia. $\mathrm{Br}$ Med $J$ 1977; ii: 1511-2.

3 Baird G M, Dossetor J F B. Letter: Methotrexate enteropathy. Lancet 1981 ; i: 164.

4 Rolles C J, Kendall M J, Nutter S, Anderson C M. Onehour blood xylose screening test for coeliac disease. Lancet 1973; ii: 1043-5.

5 Pinkerton C R, Glasgow J F T, Bridges J M, Welshman S G. Enterotoxic effect of methotrexate: does it influence the drug's absorption in children with acute lymphoblastic leukaemia? $\mathrm{Br}$ Med J 1981 ; 282: 1276-7.

6 Werkheiser W C. The relation of folic acid reductase to aminopterin toxicity. J Pharmacol Exp Ther 1962; 137: 167-72.

7 Davidson G P, Townley R R W. Structural and functional abnormalities of the small intestine due to nutritional folic acid deficiency in infancy. J Pediatr 1977; 90: 590-4.

8 Hughes W T, Kuhn S, Chaudhary S, et al. Successful chemoprophylaxis for Pneumocystis carinii pneumonitis. N Engl J Med 1977; 297: 1419-26.
9 Hitchings G H. Species differences among dihydrofolate reductases as a basis for chemotherapy. Postgrad Med J 1969; 45: Supplement, 7-10.

10 Hughes D T D. Use of combinations of trimethoprim and sulphamethoxazole in the treatment of chest infections. Med J Aust 1973; i: Special supplement, 58-61.

11 Girdwood R H. Trimethoprim/sulphamethoxazole: long term therapy and folate levels. Med J Aust 1973; i: Special supplement, 34-6.

12 Chanarin I, England J M. Toxicity of trimethoprim sulphamethoxazole in patients with megaloblastic haemopoiesis. Br Med J 1972; i: 651-3.

13 Blackwell E A, Hawson G A T, Leer J, Bain B. Acute pancytopenia due to megaloblastic arrest in association with co-trimoxazole. Med J Aust 1978; ii: 38-41.

14 Pinkel D. Five year follow up of 'total therapy' of childhood lymphocytic leukemia. JAMA 1971; 216: 648-52.

15 Shalet S M, Beardwell C G, Morris Jones P H, Pearson D. Growth hormone deficiency after treatment of acute leukaemia in children. Arch Dis Child 1976; 51 : 489-93.

Correspondence to Dr I J Lewis, Alder Hey Children's Hospital, Eaton Road, Liverpool L12 2AP.

Received 17 May 1982 